\title{
La protección de los consumidores $y$ usuarios en materia de precios
}

Federico Cristofol de Alcaraz

El artículo 51 de la Constitución de 27 de Diciembre de 1978, establece básicamente que los poderes públicos, garantizarán la defensa de los consumidores y usuarios mediante mecanismos legales eficaces que protejan la seguridad, la salud y los legítimos intereses económicos de los mismos.

Por lo interesante que puede ser para el consumidor, pretendemos centrar éste pequeño trabajo en lo referente a materia de precios de bienes y servicios que, con caracteres usuales, se ofertan en una sociedad eminentemente consumista como la nuestra.

Como antecedente legal posterior a la Constitución, aparece en este aspecto, el Real Decreto 1945/1983 de 22 de junio, por el que se regulan las infracciones y sanciones en materia de defensa del consumidor y de la protección agro-alimentaria. Esta disposición nace no sólo para difundir y actualizar las normas vigentes en materia de inspección y vigilancia de las actividades alimentarias y de sanción de las infracciones, sino también, y entendemos que con carácter especial, para evitar indefensiones individuales o colectivas ante el fraude, la adulteración, el abuso o la negligencia.

Pero una norma como ésta, con su publicación en el Boletín Oficial del Estado, puede carecer de la efectividad práctica que persigue, si no se ponen a disposición de los ciudadanos unos elementos de juicio que les perimitan discrnir entre lo que deben exigir y lo que deben denunciar ante cualquier situación irregular.

Tanto el Ministerio de Sanidad y Consumo, el Instituto Nacional del Consumo, Comunidades Autónomas, Ayuntamientos, Diputaciones, Asociaciones de Consumidores y medios de información, están extendiendo y divulgando ampliamente esos elementos de valoración y juicio para que el ciudadano de a pie, el consumidor, pueda tener, en un momento dado, un conocimiento y en definitiva una educación, lo más exactos posible para ejercer y exigir sus derechos y a la vez cumplir con sus obligaciones. Pero aún a pesar de éstas divulgaciones de todo punto positivas, queda mucho camino por recorrer para que el usuario o consumidor tenga conciencia de la realidad comercial que le rodea y pueda autodefenderse frente a posibles agresiones fraudulentas o abusivas.

Poniendo nuestra atención en la materia que nos ocupa, cual es la de la protección de los consumidores en materia de precios, hemos de seañalar que el Real Decreto indicado más arriba, regula especialmente en su artículo 3. , 3.2 , las infracciones en materia de transacciones comerciales, condiciones téc- 
nicas de venta y en materia de precios, considerando como tales infracciones, entre otras:

A) La venta al público de bienes o la prestación de servicios a precios superiores a los máximos legalmente establecidos o con incumplimiento de las disposiciones o normas urgentes en materia de precios y márgenes comerciales.

B) La ocultación al consumidor o usuario de parte del precio mediante formas de pago o prestación no manifiesta o mediante rebajas en la cantidad ó calidad reales respecto a las prestaciones aparentemente convenidas.

C) La imposición de condiciones que supongan una prohibición de vender a precios inferiores a los mínimos señalados por el productor, fabricante o distribuidor de productos singularizados por una marca registrada.

D) Toda acción u omisión, ya sea individual o colectiva que constituya paralización o amenaza de ella, de una actividad comercial o de prestación de servicios al público, siempre que sea realizada con el propósito de rehuir el aumplimiento de las disposiciones en materia de precios, ordenación de transacciones comerciales o régimen de servicios, con perjuıcıó aırecto o inmearato para el consumidor o usuario.

Tenemos, pues, tipificadas en cierta forma, aquellas infracciones que contempla la normativa vigente en materia de precios, si bien, la Ley 26/1984 de 19 de julio para la defensa de los consumidores y usuarios, también recoge infracciones de ésta materia, pero lógicamente, de una forma más generalizada y la que necesariamente habrá de ser objeto de un desarrollo reglamentario posterior, más pormenorizado.

¿Qué constituye, en realidad, la protección al consumidor en materia de precios? En principio hay que pensar y dejar sentado que, al hallarnos en una sociedad de libre mercado como reconoce el artículo 38 de la Constitución, los bienes y servicios que se ofertan gozan de una liberalización en sus precios, no sujetos a intervencionismo por parte de las Administraciones Públicas, salvo aquellos que expresamente sean autorizados o comunicados en virtud del Real Decreto 2.695/1977 de 28 de octubre, sobre normativa en materia de precios.

La intervención de la Administración en la regulación y control de precios ha venido reduciéndose, en aras de su liberalización, en los últimos diez affos, de una manera considerable, sobre todo si tenemos en cuenta que, desde abril de 1975 y como consecuencia de determinadas medidas relativas a política de precios, se ha pasado de unas listas numerosas de productos o servicios sujetos tanto al régimen de precios autorizados como de vigilancia especial, a una relación numérica de, apenas treinta y cuatro, entre bienes y servicios, sometidos a control de la Administración en junio de 1983.

Ello quiere decir, sin más, que toca al consumidor, la elección, dentro de ésta libertad comercial, del producto, bien o servicio que sea más favorable a su economia, conforme a las ofertas que reciba. Es por eso, por lo que cada vez debe recalcarse más y repetirse hasta la saciedad que el usuario o consumidor debe educarse para saber escoger y decidir entre las distintas ofertas, puesto que la tendencia actual de la Administración es la de abandonar ese excesivo proteccionismo cuasi paternalista que en otros momentos acometió, guiada 
quizá por unas necesidades de política económica que hoy, posiblemente, no estarian justificadas en el marco de libertades que ampara el Texto Constitucional.

No obstante, queda subsistente que, a aquellos bienes y servicios que no estén sometidos ni al régimen de precios autorizados ni al de precios comunicados sólo serán aplicables los márgenes comerciales o de distribución que en el futuro establezca el Ministerio de Economía y Hacienda, atendiendo a las circunstancias especiales del mercado, por lo que, cabe pensar que la Administración se hace una reserva para regular aquellos casos que pudieran considerarse especiales. (O.M., 5 de marzo de 1984).

De todas formas, entendemos que, en la actualidad no se ha alcanzado todavía el nivel de responsabilidad individual ni colectiva frente a aquellas agresiones que, a veces, sufren los consumidores y que suelen producirse, sin pruebas, dejando también a los órganos de la Administración competentes, imposibilitados para actuar. Y más, cuando hay un aprovechamiento de la buena fe del consumidor, que la deposita quizá por desconocimiento, cuando se encuentra sujeto a una transacción comercial, bien por imperiosa necesidad o bien por mero afán consuntivo.

Pero, siempre quedan a la Administración resortes para ejercer su control, haciendo uso de normas que, si no son totalmente clarificadoras, sí son, tendentes a un moderado intervencionismo. Pongamos como ejemplo, el artículo $8 .^{\circ}$ del Real Decreto $2.695 / 1977$ de 28 de octubre, que deja previsto que las elevaciones de los precios de determinados bienes y servicios no requerirán autorización ni comunicación a la Administración, pero no obstante, la Junta Superior de Precios podrá examinar de oficio o a instancia de parte, los precios practicados en cualquier bien o servicio que pudieran parecer anormales o injustificados.

Estamos ante la posibilidad de que la Administración intervenga por sí o impulsada por el administrado, cuando se advierta tan sólo un presunto abuso, sea éste por anormalidad o por iniustificación.

Queda, pues, una luz abierta al consumidor o usuario para exigir de la Administracion que se le proteja en el derecho que le reconoce la Constitucion. Esa luz o vía podrá utilizarla en su defensa, siempre y cuando pueda probarse definitivamente que el precio pagado por la prestación de un servicio o la adquisición de un bien no se encuentra dentro de los límites que sirven comúnmente para calificarlos dentro de una norma o regla o conforme a justicia y razón. Pero lo que es innegable es que la Aministración viene obligada a proteger a los consumidores, siendo responsabilidad de ella buscar los cauces y procedimientos eficaces que sirvan para garantizar ésta protección, sea en su seguridad, en su salud, o en sus legítimos intereses económicos, y ésto, independientemente de que sea, como es también su obligación y tarea, el promover la información y la educación debida de los consumidores y usuarios. No podemos considerar, por tanto, que el ciudadano, se encuentre indefenso o desprotegido. La Administración debe contar con resortes legales suficientes para dar respuesta a sus problemas. 